DOI: 10.24100/MKF.2017.04.167

\title{
Oláh György (1927-2017) emlékezete
}

\author{
HARGITTAI István *,1 \\ Budapesti Müszaki és Gazdaságtudományi Egyetem Vegyészmérnöki és Biomérnöki Kara Szervetlen és Analitikai Kémia \\ Tanszéke, Szent Gellért tér 4, 1111 Budapest, Magyarország
}

\section{Bevezetés}

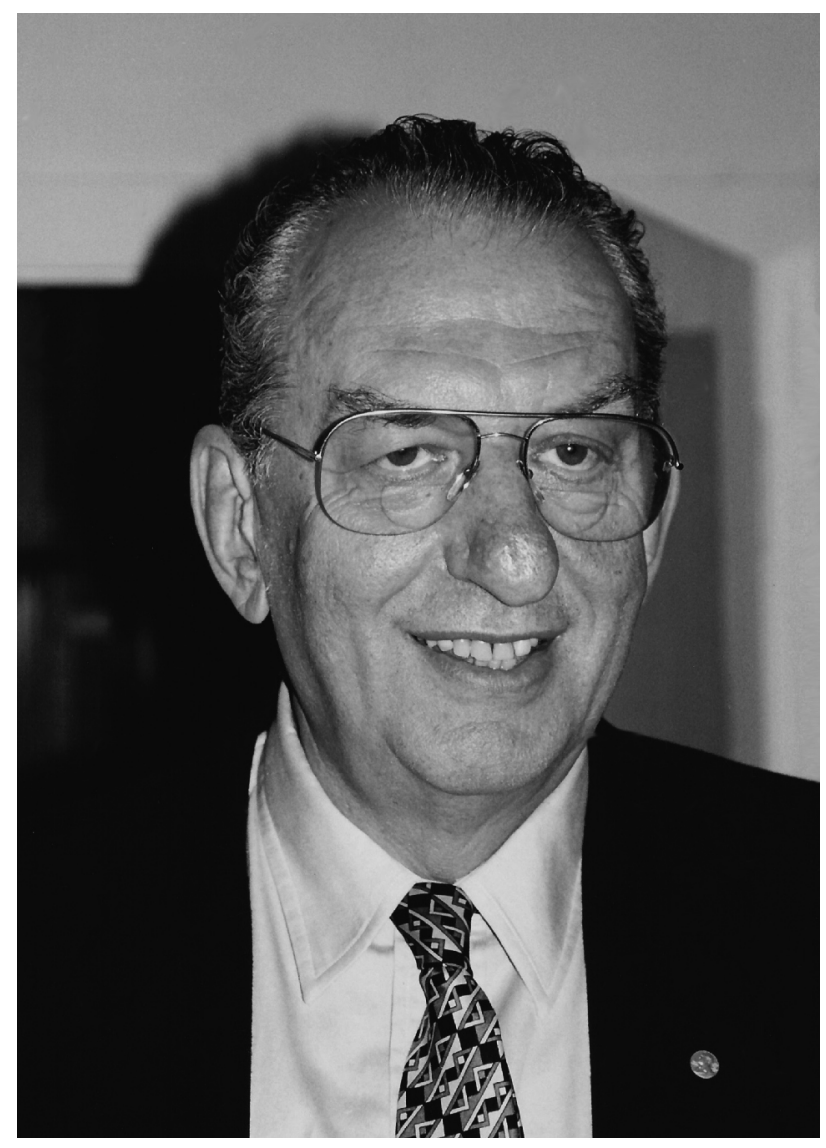

1. Ábra. Oláh György 1995-ben a szerző műegyetemi szobájában (Hargittai I. felvétele).

Oláh György 1927. május 22-én született Budapesten és 2017. március 8-án halt meg Los Angelesben. Életének első másfél évtizede polgári jólétben telt, szüleivel és három évvel idősebb Péter nevű bátyjával boldog családot alkottak és az Operaházzal szemben a VI. kerület Hajós utca 13-15. szám alatti ház egyik lakásában laktak. Oláh a Piarista Gimnáziumba járt, ahogy előtte bátyja is. Az 1930-as évek végétől a zsidóellenes törvények megjelenésével azonban a külső körülmények egyre több nehézséget okoztak a család és Oláh György életében. Eleinte a család katolikussága és a Piarista Gimnázium toleránssága még enyhítést jelentett, de a Vészkorszak utolsó idejében Oláhnak már bújkálnia kellett és életbenmaradását a legendás evangélikus lelkész Sztehlo Gábor gyermekmentő akciójának köszönhette. Bátyja nem élte túl a háborút. Hasonló sorsa volt Oláh későbbi feleségének, született Lengyel Juditnak, aki megszökött egy a nyilasok által terelt menetböl és bújkált a felszabadulásig, de a menetben maradt nővérét megölték.

\footnotetext{
* Tel. 361463 3407, e-mail: istvan.hargittai@gmail.com. Ebben a Magyar Kémiai Folyóirat főszerkesztőjének felkérésére írt cikkben szabadon merítettem a közelmúltban Oláh Györgyről megjelent írásaimból. Lásd 1. hivatkozás.
} 


\section{Tanulmányok}

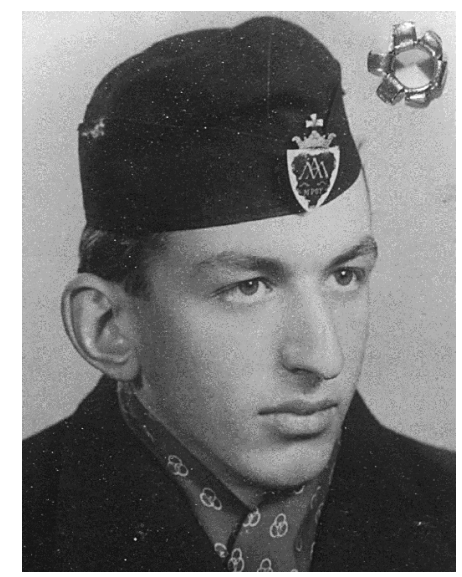

2. Ábra. A gimnazista Olah György (néhai Oláh György szívességéböl).

A Piarista Gimnázium minden jel szerint kiválóan megalapozta Oláh széleskörü érdeklődését és általános műveltségét. Gimnáziumi évei alatt még inkább író vagy történész szeretett volna lenni, de ez a háború után megváltozott. Felismerte, hogy mérnökként, kutatóként nagyobb esélye lesz a boldogulásra, mint valamilyen humán területen. A háború utolsó évében átélt megpróbáltatások sem késztették arra, hogy akárcsak egy percet is kihagyjon, inkább kemény munkával válaszolt a kihívásokra. Leérettségizett, majd beíratkozott a Műegyetemre, ahol a nyolc félév elvégzése után 1949. tavaszán befejezte tanulmányait. Diplomájának dátuma 1949. június 24.

Tanítómestere Zemplén Géza professzor volt, akkoriban a magyarországi szerves kémia vezető tudósa és akinek a tanszékére a végzés után Oláh azonnal tanársegédi kinevezést kapott. Ugyanakkor Oláh aspiránsként is bekapcsolódhatott a tudományos minősítés rendszerébe, 1953-ban beadta és 1954-ben megvédte kandidátusi disszertációját. A disszertáció szerves fluorvegyületek előállításáról és kémiájáról szólt. A disszertáció az MTA Könyvtárának Kézirattárában található és amikor érdeklődtem Oláhnál, hogy 90. születésnapjára készülő írásomban idézhetek-e belőle, nemcsak engedélyt adott erre, de bátorított is a disszertáció anyagával való megismerkedésre. Ebben a munkában Oláh freonreaktort épített.

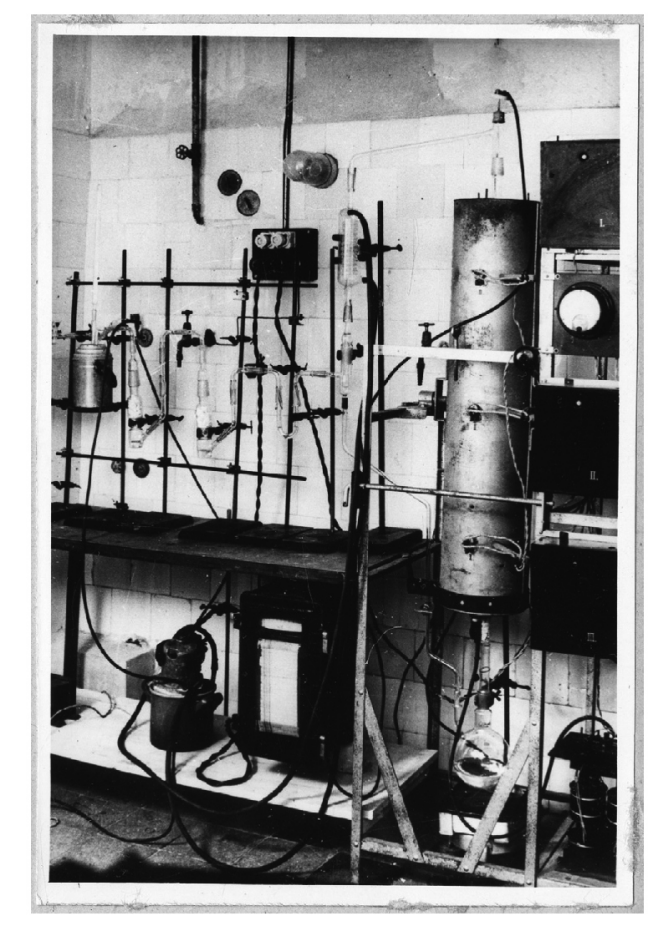

3. Ábra. Oláh György freonreaktora. A fénykép kandidátusi disszertációjából való. 
A munka jelentőségét és nehézségeit Oláh a következőképpen látta a diszertáció szavai szerint:

Hazai viszonyok között szerves fluórvegyületek elöállításával eddig egyáltalában nem foglalkoztak. Ennek oka elsősorban a vegyületek előállításának preparatív nehézségeiben keresendő. A fluórkémia nálunk nagyjában úgy lett kezelve, mint platina-edényzetet igénylő rendkívül költséges és veszélyes terület, amelynek különösebb gyakorlati jelentősége nincsen. A külföldi irodalomban napvilágot látott közleményeket, amelyek igen elönyös tulajdonságú fluór-tartalmú műanyagok és egyéb származékok előállítását tartalmazták, nálunk úgy fogadták, mint csak a "fejlett" külföldön megvalósítható eredményeket és ezen származékok hazai körülmények közt való előállítását nem tartották lehetségesnek. Mindezt összefoglalva a szerves fluórvegyületek elóállításával való foglalkozás nálunk kevés reménnyel kecsegtető feladatnak látszott, amelytől vegyészeink meglehetősen idegenkedtek.

Az értekezés 186 oldalas, tele van kézzel rajzolt képletekkel és reakciókkal és sok új szintetikus kémiai megoldásról számol be. A disszertációba fektetett munka volumene sokkal nagyobb volt, mint önmagukban az új eredmények, mert Oláhnak sok esetben olyan reaktánsokat is elő kellett állítania, amelyekhez másutt kereskedelmi forgalomban könnyen hozzá lehetett férni. A kandidátusi munka eredményeit Oláh tizenhat publikációban közölte, köztük egy 12-részes cikksorozatban, amelynek több tagja magyarul és angolul is megjelent, az utóbbi a ma már nem létezö Acta Chimica Hungaricában. Több dolgozatban Pavláth Attila szerepel társszerzőként, aki a Müegyetemen Oláh tanítványa volt, később neves amerikai kémikus és az Amerikai Kémiai Társaság elnöke is lett. Oláh két szabadalmi bejelentést is tett, amelyekben találmányait írta le. Az értekezés külön is hangsúlyozza találmányok jelentőségét a freonvegyületek (klórt és fluort tartalmazó szénhidrogének) ipari elóállitásában. Két további dolgozatot Oláh orvosegyetemi munkatársakkal együtt publikált. Ezekben fluórvegyületek hatásáról számolnak be olyan állatok állapotára, amelyekben mesterségesen daganatot idéztek elö. Ezek közül az egyik cikk a német Archiv für Geschwulstforschung címü onkológiai folyóiratban jelent meg. Az orvosbiológiai kutatásokhoz Oláh beiratkozott az orvosegyetemre, és elvégzett három évet. Ugyanebben az időben oroszul is tanult, és a kandidátusi fokozat megszerzéséhez szükséges szakmai vizsgákat és a nyelvvizsgát kiváló minősítéssel tette le. Ugyancsak tanulnia kellett a kandidátusi fokozat elöírásainak megfelelő politikai tárgyakat. Oláh heti hatvannégy órányi hivatalos elfoglaltságról ad számot egyik beszámolójában, amelyből tizennégy óra diákokkal való közvetlen foglalkozás. A valóságban heti hatvannégy óránál sokkal többet dolgozott.

Oláh pályájának ebben a szakaszában a hazai tudományos életben hatalmas változások történtek. Ezek közé tartozott a Központi Kémiai Kutatóintézet megalakítása, amelynek Schay Géza lett az igazgatója és Oláh Györgyöt igazgatóhelyettesnek nevezték ki. Ennek a kinevezésnek a jelentőségét növelte, hogy Schay, aki akkkor már jó ideje nagy tekintéllyel rendelkezett, kevéssé vett részt a mindennapok intézeti tevékenységében és a feladatok jórésze Oláhnak jutott. A Schayjal való kapcsolat azonban Oláhra is jótékony hatással volt, Schay kutatói és emberi kvalitásai minden bizonnyal gazdagították Oláh tapasztalatait. Az oktatás és vezetési tevékenység mellett Oláh kutatásai nem lassultak le és már 1956-ban benyújtotta "nagydoktori” disszertációját. Ez az értekezés az MTA Könyvtárának Levéltárában található. A Levéltár őrzi a meg nem védett értekezéseket ?Oláh akadémiai doktori értekezésének megvédésére már nem kerülhetett sor. Az értekezés az aromás elektrofil helyettesítési reakciók mechanizmusáról szól és ennek a munkának az eredményeit Oláh már tekintélyes nemzetközi folyóiratokban publikálta, ezek a következök voltak: Nature, The Journal of the Chemical Society, Chemische Berichte, Naturwissenschaften. Oláh szerzötársai Pavláth Attila és Kuhn István (később Amerikában Steven) voltak. Oláh egész tevékenységét a hatalmas munkabírás és lelkesedés jellemezte. Ugyanakkor, ne felejtsük el, hogy az 1950-es évek első felében a bizalmatlanság légköre hatotta át a magyarországi életet. Oláhról is írtak jelentéseket kollégái, de igazán terhelő adatokat az Állambiztonsági Szolgálatok Történeti Levéltárának anyagai szerint ezek a jelentések nem tartalmaztak. Talán a legsúlyosabb "vád" ellene az volt, hogy "polgárgyerek" aki hol baloldaliságával hol jobboldaliságával tünt ki.

\section{Irány Észak-Amerika}

Oláh és családja 1956 novemberében hagyta el Magyarországot. A hazai helyzetet kilátástalannak ítélte nagyformátumú tudományos kutatási tervei szempontjából. Azonban a távozáshoz a Vészkorszakban megélt tragédiák emlékei is hozzájárultak, a megaláztatások és a háborút követő időkben az átélt tragédiák kibeszéletlensége. Oláh és felesége ekkor azt is eldöntötte, hogy lezárja a múltat és újra indítja az akkor már háromtagú, majd hamarosan négytagú család történelmét. Elöször Londonban álltak meg, ahol Oláh felvette a kapcsolatot olyan kémiai nagyságokkal, mint Alexander Todd és Christopher Ingold, akiket addig csak az irodalomból ismert. Még fontosabb volt az akkor még szintén pályája elején tartó Ronald Gillespie-val való megismerkedése.

Oláhék Kanadát célozták meg, ahol a háború vége óta Lengyel Judit édesanyja élt. Oláh szeretett volna egyetemi álláshoz jutni, de ez nem sikerült. Évekkel később, amikor Oláh már nemzetközi hírü elismert tudós volt kapott egy levelet a Torontói Egyetem egyik szerves kémia professzorától. A professzor tulajdonképpen bocsánatot kért azért, hogy annak idején megakadályozta Oláh kinevezését a Torontói Egyetemre, mert túlságosan nagy kockázatot látott abban, hogy egy ismeretlen menekültet maguk közé fogadjanak. Oláh a Dow cég sarniai kutatólaboratóriumába került és amit ott produkált meghatározta további pályáját és sikereit és nagyszerủ példát is mutatott kitartó és elszánt elkötelezettségére a tudomány iránt. A munkaidő alatt maradéktalanul teljesítette a 
vállalati feladatokat, azután, a mukaidőn kívül folytatta Budapesten elkezdett kutatásait. Főnökei értékelték tudását, szorgalmát, lelkiismeretességét és invenciózusságát. Megengedték Oláhnak, hogy használja kutatásaihoz a Dow laboratórium eszközeit és publikálja eredményeit. Oláh szemináriumokat szervezett meghívott előadókkal és hamarosan őt is kezdték előadástartásra felkérni. A laboratóriumi vezetés csak egy dologban bizonyúlt túlságosan konzervatívnak, nem ismerték fel az NMR spektroszkópia fontosságát és ezekhez a vizsgálatokhoz Oláh kénytelen volt egyetemi tanszékek segítségét igénybe venni. Ez már csak azért sem volt nehéz, mert kiváló kapcsolatokat alakított ki az akadémiai életben tevékenykedő kollégáival. Az egyik NMR-es laboratórium, ahová vizsgálandó mintáit elküldhette Gillespie tanszéke volt a viszonylag közeli McMaster Egyetemen.

\section{Karbokation kémia}

Amint már láttuk, Gillespie-vel személyesen Londonban ismerkedett meg. Időközben Gillespie is Kanadába került, de merőben más feltételekkel, mint Oláh. Gillespie-t meghívták a tekintélyes McMaster Egyetemre és Gillespie maga szabhatta meg alkalmazásának feltételeit, amelyek között szerepelt egy korszerű NMR berendezés beszerzése is. Az NMR mérések biztosítása Oláh számára csak egy volt Gillespie és Oláh kutatói pályájának átfedései között. Legfontosabb a szupersavak iránti közös érdeklődésük volt és ebben Gillespie már korábban jelentős eredményeket mutatott fel. Egyik könyvének előszavában Oláh külön is köszönetet mond Gillespie-nek a szupersavak területén elért úttörő eredményeiért. Gillespie másik fontos és nemzetközileg ismert kutatási eredménye a szervetlen vegyületek molekulaszerkezetének megállapításában hasznos vegyérték-héj elektronpár taszítási (VSEPR) model megteremtése volt. Én ezen a területen kerültem vele kapcsolatba és közös könyvet is megjentettünk erről a modellröl. Gillespie és Oláh kapcsolatát a kölcsönös tisztelet és egymás elismerése jellemezte. Nézeteltérés (nem igazán komoly) közöttük csak egyetlen kérdésben volt. Mindkettőjükkel (külön-külön) beszélgettem azokról a tapasztalatokról, amelyek arra az időre vonatkoztak, amikor Oláh mintáit Gillespie NMR készülékében vizsgálták. Gillespie szerint Oláh jól tette, hogy nem törekedett a minták abszolút tisztítására, mert így nem "tisztította ki" a mintákból azt, amit később karbokationnak nevezett el és ami lehetővé tette korszakos felfedezését. Oláh szerint viszont a minták tisztaságával nem volt semmi probléma.

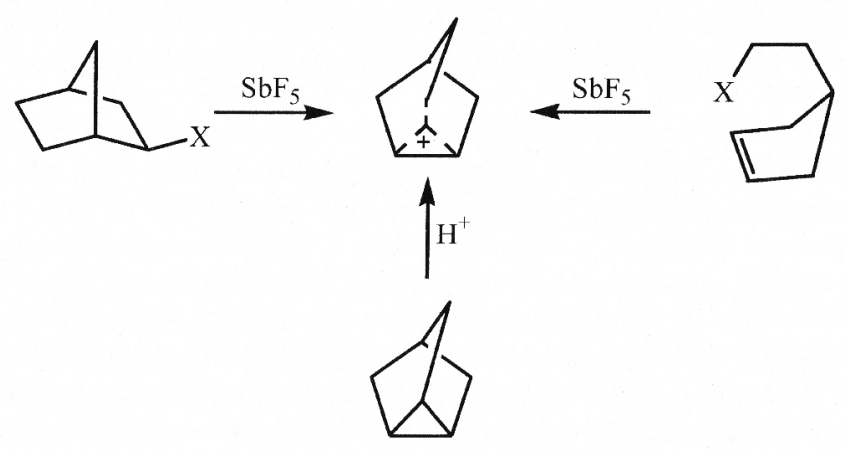

4. Ábra. A hosszúéletű nem-klasszikus 2-norbornilionhoz vezető utak.<smiles>[IH][IH]</smiles>

$\mathrm{H}_{3}^{+}$<smiles>CC</smiles>

methonium ion

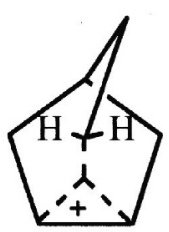

norbornyl ion<smiles>C[C+]1CC1</smiles>

corner protonated cyclopropane<smiles>[C]1CCC1</smiles>

edge protonated cyclopropane

5. Ábra. Jellegzetes nem-klasszikus ionok. 
Oláh felfedezésének lényege az volt, hogy szupersavak segítségével hosszabb életűvé tette az átmeneti termékként addig azonosíthatatlan karbokationokat. A felfedezés igazi jelentősége abban rejlett, hogy a szén-szén és a szén-hidrogén kovalens kötést reakcióképessé tette és ezáltal az addig nem igazán izgalmas szénhidrogén kémiából egy új kémiát teremtett. A felfedezés nem egy hirtelen felismerésből született, hanem hosszú évek aprólékos kisérletezéseiből, a szintetikus kémia és a fizikai módszerek és a számításos kémia együttes alkalmazásából. Először 1962-ben lépett a nyilvánosság elé Oláh olyan eredményekkel, amelyek azonnal óriási figyelmet kaptak. Ez egy Brookhavenben rendezett, a szerves vegyületek kémiai reakcióinak mechanizmusával foglalkozó konferencián történt, amelyen Oláh meghívott előadást tartott. Ebben az időben már évek óta folyt egy híres vita arról, hogy a 2-norbornil észterek hidrolízise során átmeneti termékként keletkező 2-norbornilion „klasszikus” vagy „nem-klasszikus” szerkezetü-e. A 2-norbornil észter exo származéka sokkal gyorsabban hidrolizál, mint az endo származék. Saul Winstein szerint az exo esetében a nagy sebesség egy „nem-klasszikus” ion hidas szerkezetének és a C1 - C6 kovalens kötés elektron-delokalizációjának volt a következménye. Herbert C. Brown viszont az endo származék lassú reakcióját térbeli gátlásnak tulajdonította, ami a „klasszikus” háromértékű ionok egyensúlyához vezetett. Weinstein és Brown korának két vezető szerves kémikusa volt és vitájukat a kémikusok közössége nagy figyelemmel kísérte. A kísérleti adatok valódiságát senki sem vitatta, nézeteltérés csak a megfigyelések értelmezésére vonatkozott. Oláh bekapcsolódása ebbe a vitába és az, hogy idővel el is döntötte a vitát (a nem-klasszikus ion létezésének igazolásával) őt is reflektorfénybe helyezte. Ennél jobban nem is debütálhatott volna a nemrég még menekült és egy ipari laboratóriumban dolgozó magyar-kanadai kutató.

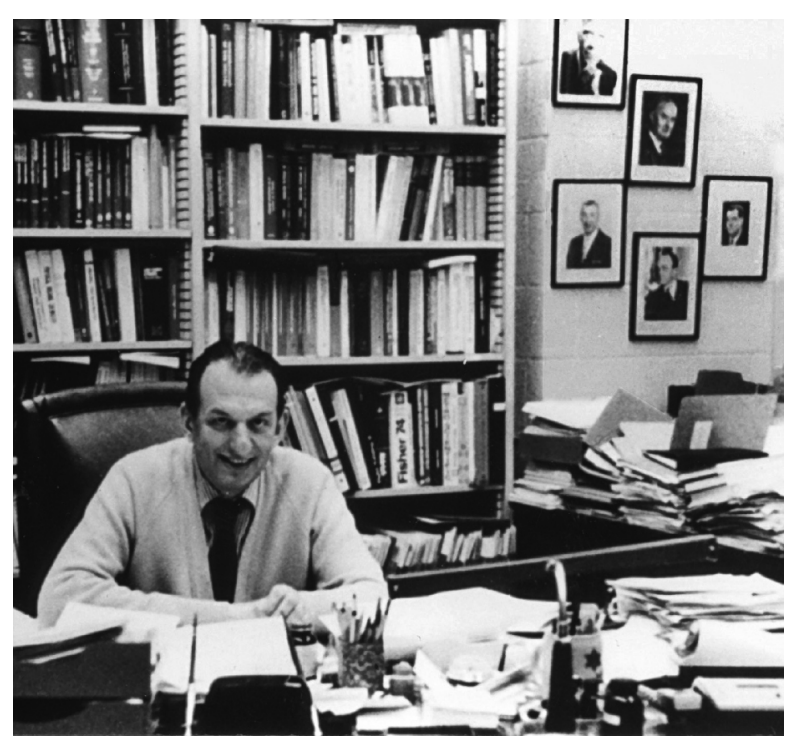

Oláh 1965-ben került vissza az akadémiai-egyetemi életbe, amikor elfogadta a clevelandi Western Reserve Egyetem felkérését a kémiai tanszék vezetésére. Röviddel ezelőtt még a Dow cég munkatársaként az Egyesült Államokba került és Clevelandban indult el igazán amerikai pályája. Miután előbb a Western Reserve Egyetem és a szomszédos Case Müszaki Egyetem kémiai tanszékei (Oláh kezdeményezésére) egyesültek, majd a két egyetem is, ma ez az intézmény a Case Western Researve Egyetem. Innen ment tovább Oláh és egész laboratóriuma a Los Angeles-i Dél-Kalifoniai Egyetemre, ahol a számára létrehozott Loker Szénhidrogén Intézetben folytatta munkáját, élete végéig.

6. Ábra. Oláh György 1976-ban clevelandi dolgozószobájában. A falon Hans Meerwein, Christopher Ingold, Saul Weinstein, Herbert C. Brown és Frank Whitmore fényképe látható (néhai Oláh György szívességéből).

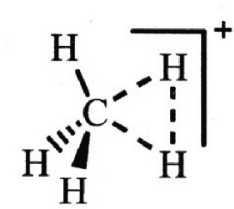

$$
\mathrm{CH}_{5}{ }^{+} \mathrm{C}_{\mathrm{s}}
$$

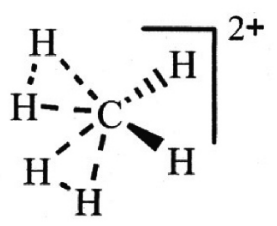

$\mathrm{CH}_{6}{ }^{2+} \mathrm{C}_{2 v}$<smiles>[13CH3][13CH2][13CH3]</smiles>

$\mathrm{CH}_{7}{ }^{3+} \mathrm{C}_{3 v}$

7. Ábra. Kételektronos kétcentrumú és kételektronos háromcentrumú kötések protonált alkánokban.

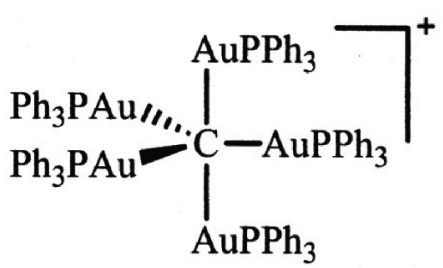<smiles>C[C+](C)c1ccccc1</smiles>

8. Ábra. Az egy pozitív töltésü $\left\{\left[\left(\mathrm{C}_{6} \mathrm{H}_{5}\right)_{3} \mathrm{PAu}\right]_{5} \mathrm{C}\right\}^{+}$karbokation trigonális bipiramisos szerkezete és a két pozitív töltésű $\left\{\left[\left(\mathrm{C}_{6} \mathrm{H}_{5}\right)_{3} \mathrm{PAu}\right]_{6} \mathrm{C}\right\}^{2+}$ karbokation oktaéderes szerkezete. 
A legjellegzetesebb nem-klasszikus karbokation a protonált metán, $\mathrm{CH}_{5}{ }^{+}$amelynek szerkezetét a kvantumkémiai számítások szerint egyetlen szimmetriasík jellemzi. Ha azonban úgy tekintjük ezt az iont, hogy a szénatomot öt elektrondomain veszi körül, amelyeket a feltételezett fluxionális viselkedés következtében nem különböztethetünk meg, akkor Gillespie VSEPR modellje szerint ${ }^{2}$ ennek az ionnak a szerkezetét trigonális bipiramisosnak, vagy tetragonális piramisosnak várnánk - ez a kettő energetikailag alig megkülönböztethető. A számítások azonban következetesen a $\mathrm{C}_{\mathrm{s}}$ szimmetriájú modellt hozzák ki legstabilisabbnak, ami három kételektronos kétcentrumú kötés és egy kételektronos háromcentrumú kötés jelenlétét feltételezi. ${ }^{3}$ Ha a $\mathrm{C}_{\mathrm{s}}$ szimmetriájú szerkezethez elég mély energiaminimum tartozik, akkor kísérletileg is megfigyelhető, feltéve, hogy a szerkezet élettartama elég hosszú a fizikai módszerben alkalmazott kölcsönhatás időtartamához képest. Ebben a vonatkozásban az NMR spektroszkópia a viszonylag hosszú kölcsönhatási idő miatt hátrányban van a diffrakciós módszerekkel szemben, de a diffrakciós módszerek hátrányban vannak a hidrogénhelyzetek meghatározásának egyértelmüsége és más gyakorlati meggondolások szempontjából. Újabb nagyfelbontású spektroszkópiai mérések is a $\mathrm{C}_{\mathrm{s}}$ szimmetriájú szerkezetre utalnak, ${ }^{4}$ de ugyanakkor erös fluxionalitásra is, mintha az öt proton állandó mozgásban lenne a szén körül. ${ }^{5} \mathrm{~A} \mathrm{CH}_{5}{ }^{+}$karbokationnak hatalmas irodalma van, amely jóval előbb kezdődött, mint maga a karbokation elnevezés. Először 1952-ben írták le egy tömegspektrometriai dolgozatban. ${ }^{6} \mathrm{~A} \mathrm{CH}_{5}{ }^{+}$karbokation trigonális bipiramisos szerkezete nem tünik különösen irreálisnak ha figyelembe vesszük, hogy egyértelmüen ez a geometria valósul meg, amikor a szénatomot nagy térigényü ligandumok veszik körül, amint ezt az egy pozitív töltésü $\left\{\left[\left(\mathrm{C}_{6} \mathrm{H}_{5}\right)_{3} \mathrm{PAu}\right]_{5} \mathrm{C}\right\}^{+}$karbokation példája mutatja. Önmagában a $\mathrm{CH}_{5}{ }^{+}$karbokation szerkezetének rejtvénye is további kutatásokat ösztönöz, lásd, például Varga Zoltán egész sorozat rokon ionra végzett vizsgálatait. ${ }^{7}$

\section{Nobel-díj és folytatás}

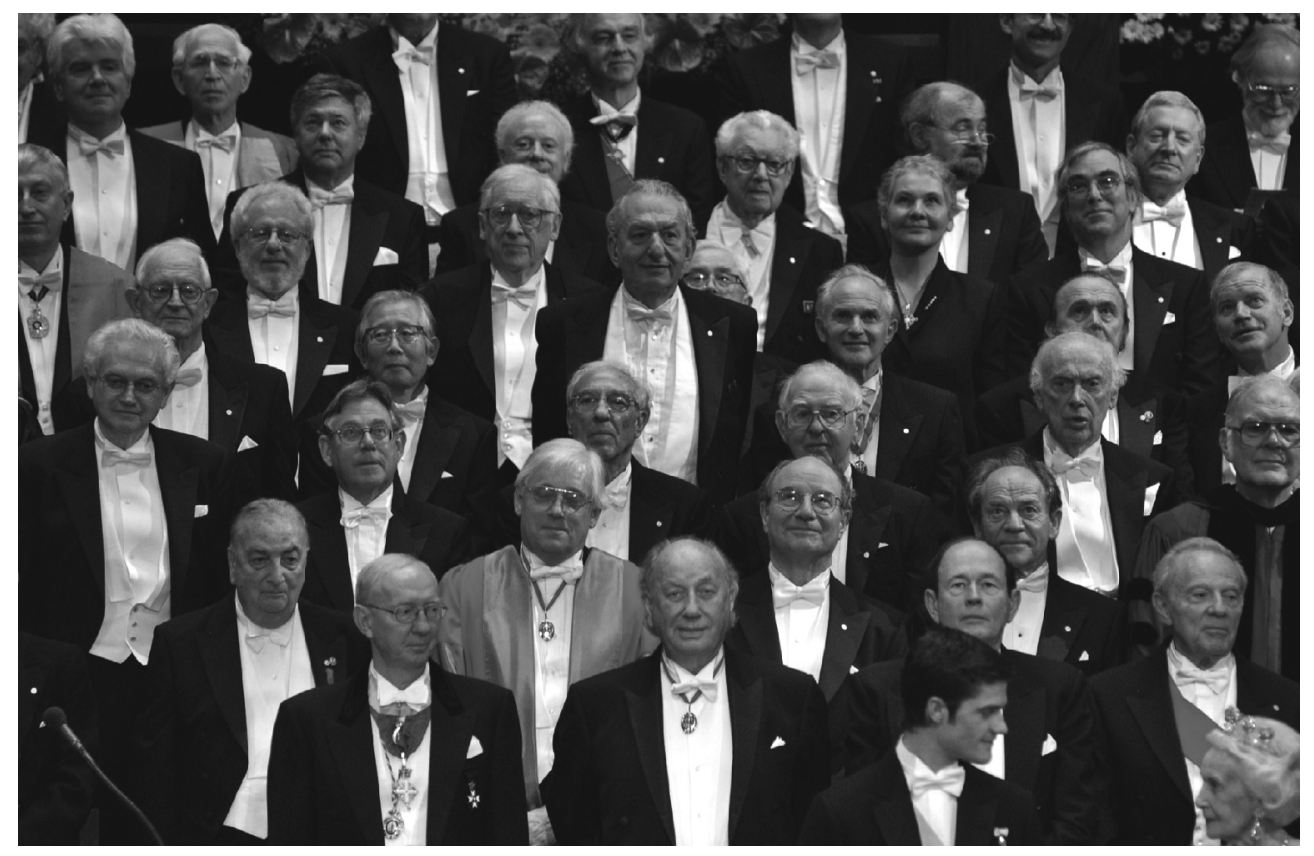

9. Ábra. Nobel-díjasok egy csoportja 2001. december 10-én Stockholmban a díjátadási ünnepségen. Különlegesen sok Nobel-díjas volt jelen, mivel a Nobel Alapítvány ugyanakkor ünnepelte a díjátadások centenáriumát (Hans Mehlin felvétele, C The Nobel Foundation, a Nobel Alapítvány szívességéből). Felülről lefelé haladva és a sorokban balról jobbra a képen a következőket láthatjuk: 7. sor, Klug, X,

Huber, X, Varmus (részben takarva), Bishop; 6. sor, Blobel, M. S. Brown, Goldstein, H. C. Brown, Neher, Gilman; 5. sor, Doherty (részben takarva), Heeger, Pople, Lewis (részben takarva), Nüsslein-Volhard, Wieschaus; 4. sor, MacDiarmid, Shirakawa, Olah, Kroto, Schally (részben takarva), Mullis; 3. sor, Nirenberg, Crutzen, E. H. Fischer, E. G. Krebs, Watson; 2. sor, Benaceraff, Walker, Gilbert, T. N.

Wiesel, Rowland; 1. sor, Samuelsson, Vane, Edelman, Jacob; 0. sor, a királyi család két tagja, Carl Philip herceg és Lillian hercegnő.

Oláh György korszakos felfedezéseit még a Dow ipari laboratóriumban tette. Legfontosabb dolgozatát a Case Western Reserve Egyetemről küldte be 1971-ben. ${ }^{8}$ Osztatlan kémiai Nobel-díját 1994-ben vehette át a karbokationok kémiájában elért eredményeiért. Oláh felfedezési már elméleti szempontból is elég jelentősek voltak ehhez a kitüntetéshez, de a díj részletesebb indoklásában a Kémiai Nobel-díj Bizottság elnöke, Saul Gronowitz konkrét alkalmazási példák bemutatásával is hangsúlyozta Oláh felfedezéseinek gyakorlati jelentőségét. ${ }^{9}$ Oláhot a Nobel-díj nem lasította le, mint ahogy a Nobel-díjasokkal többnyire történni szokot, inkább fokozta munkája iránti odaadását. Pályájának ebben az utolsó időszakában, ha lehet, még nagyobb figyelemmel fordult a gyakorlati alkalmazások felé. Arra is szakított időt, hogy munkásságát önéletrajz jellegü könyvben beszélje el, visszafogottan, szerényen, de pontosan és reálisan. Ennek első változata magyarul is megjelent. Nem sokkal halála előtt publikálta a könyv kiegészített változatát. ${ }^{10}$ Oláh sok könyvet írt és szerkesztett. Rendszerint, amikor lezárt egy témát, szerzői vagy szerkesztett monográfiában foglalta össze az eredményeket. Alább felsorolom legfontosabb könyveit. 
Friedel-Crafts and Related Reactions (szerkesztett, 4 kötet, 1963-1965)

Carbonium Ions (szerkesztett 4 kötet, 1968-1973)

Carbocations and Electrophilic Reactions (1973)

Friedel-Crafts Chemistry (1973)

Halonium Ions (1975)

Superacids (1985)

Hypercarbon Chemistry (1987, átdolgozott kiadás, 2011)

Nitration: Methods and Mechanisms (1989)

Cage Hydrocarbons (szerkesztett, 1990)

Electron Deficient Boron and Carbon Clusters (szerkesztett, 1991)

Chemistry of Energetic Materials (szerkesztett, 1991)

Synthetic Fluorine Chemistry (edited, 1992)

Hydrocarbon Chemistry (1994; 2004)

Onium Ions (1998)

A Life of Magic Chemistry (2000, átdolgozott kiadás, 2015)

Across Conventional Lines (szerkesztett válogatás, 2 kötet, 2003)

Carbocation Chemistry (2004)

Beyond Oil and Gas: The Methanol Economy (2006, átdolgozott kiadás, 2009)

Superelectrophiles and Their Chemistry (2008)

Superacid Chemistry (2009)

Across Conventional Lines (szerkesztett válogatás, 3. kötet, 2014)

Magyarul is megjelent Életem és a mágikus kémia és a Köolaj és földgáz után: A metanolgazdaság. A magyar nyelven olvasók számára különösen szerencsés, hogy Oláh György, Csákvári Béla szerkesztő felkérésére, A Kémia Újabb Eredményei könyvsorozat jubileumi, 100. kötetének egyik fejezeteként összefoglalta kutatási eredményeit. ${ }^{11}$

Az elmúlt negyed században személyes kapcsolatunkban sokat köszönhettem Oláh Györgynek, többek között, ő kezdeményezte sokoldalú és nagyon konstruktív svéd kapcsolatainkat. Eredetileg a szimmetria iránti közös érdeklődésünk hozott össze bennünket. Támogatta a Chemical Intelligencer folyóirat megindítását, ami sok további izgalmas esemény kiindulópontja lett. Amikor munkahelye, a Dél-Kaliforniai Egyetem elindította a George Olah Lectureship évente megrendezett előadásait, az Egyetem Oláh javaslatára engem kért fel az első előadás megtartására, amelyre 1996 februárjában került sor.

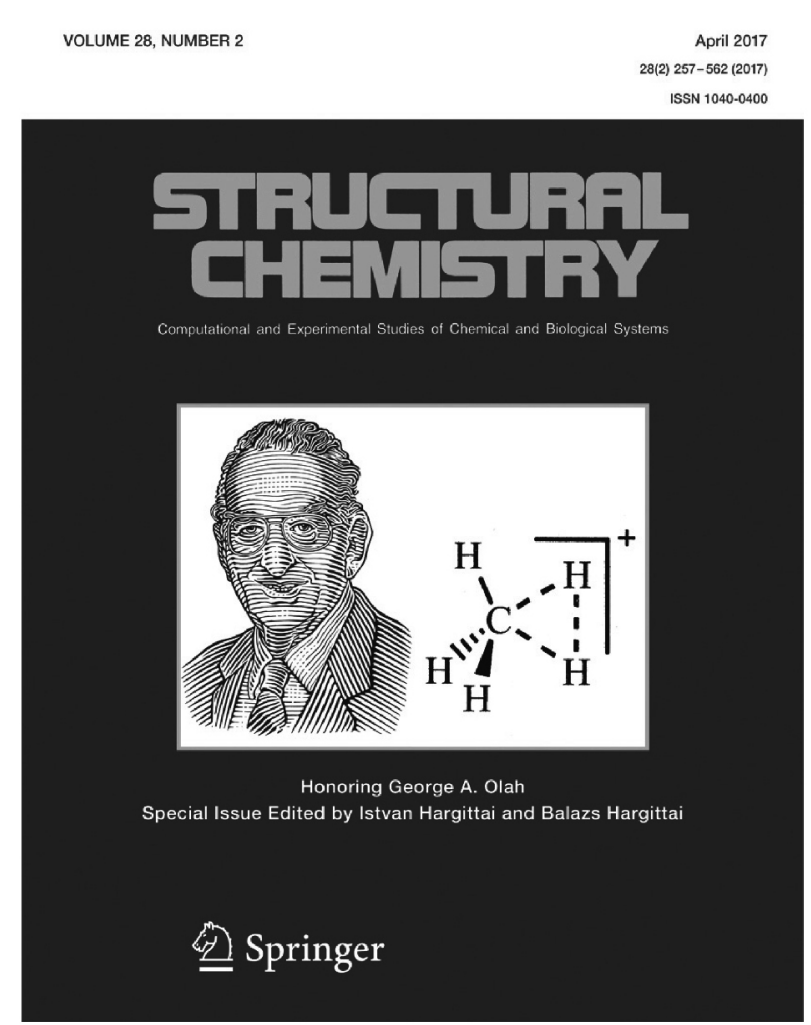

10. Ábra. A Structural Chemistry Oláh György tiszteletére szerkesztett különszámának (2017. április) ${ }^{12}$ borítója Orosz István grafikájával. 
Az elmúlt másfél évben Hargittai Balázzsal közösen a Structural Chemistry nemzetközi folyóiratban különszámot szerveztünk Oláh György közelgő 90. születésnapja tiszteletére. Oláh figyelemmel kísérte a különszám készülését és amikor megismerkedett a tartalmával, valamint tudva a Kémiai Tudományok osztálya által 2017. május 3-ra tervezett előadóülésről, a következő üzenetet kaptam tőle:

Kedves István,

szívből köszönöm neked és Balázsnak az igazán megható sorokat. Veled küldöm mindenkinek köszönetemet és legjobb kívánságaimat.

Ha alkalom lesz az akadémiai eseményen, mondjál köszönetet mindenkinek. Sajnos nem tudok jelen lenni és köszönetemet személyesen is átadni mindenkinek.

Baráti üdvözlettel,

Gyuri.

Ez volt tőle az utolsó üzenet. 2017. március 8-án kaliforniai otthonában elhúnyt. Így aztán a május 3-i előadóülésből, amelyet Huszthy Péter szervezett, emlékülés lett. Oláh György emléke felfedezései, embersége, a tudomány iránti elkötelezettsége velünk marad és a következö generációkat is gazdagítja majd.

\section{Hivatkozások}

1. Hargittai, I. "Structure and mechanisms in chemical reactions: George A. Olah's life-long search of chemistry." Structural Chemistry, 28, pp. 259-277, 2017. https://doi.org/10.1007/s11224-016-0814-x;

Hargittai I. “Oláh György (1927-2017): A tudós és habitusa.” Magyar Tudomány 2017. áprilisi szám, 438-449;

Hargittai, B., Hargittai, I. “George A. Olah (1927-2017).” Structural Chemistry, 28, pp. 563-564, 2017.

Https://doi.org/10.1007/s11224-017-0945-8;

Hargittai, I. “George A. Olah (1927-2017): An Introduction.” Periodica Polytechnica - Chemistry 2017, megjelenés alatt. https://doi.org/10.1007/s11224-016-0814-x

2. Gillespie RJ, Hargittai I (2012) The VSEPR model of molecular geometry (Reprint edition; original edition 1991). Dover, Mineola, New York.

3. Lásd például: Olah GA (2015) A life of magic chemistry: autobiographical reflections including post-Nobel prize years and the methanol economy. Second updated edition (with Mathew T). Wiley, Hoboken. https://doi.org/10.1002/9781118840108

4. Asvany O, Yamada KMT, Brünken S, Potapov A, Schlemmer S (2015) Experimental ground-state combination differences of $\mathrm{CH}_{5}^{+}$. Science 347:1346-1349. https://doi.org/10.1126/science.aaa3304

5. Oka T (2015) Taming $\mathrm{CH}_{5}{ }^{+}$, the "enfant terrible" of chemical structures. Science 347:1313-1314 https://doi.org/10.1126/science.aaa6935

6. Tal'rose VL, Lyubimova AK (1952) Gas-Phase Ion/Molecule Reactions. Dokl Akad Nauk SSSR 86:909-912.

7. Varga Z (2017) About the structure of $\mathrm{CH}_{5}{ }^{+}$and structural variations in related systems. Struct Chem 28:297-301. https://doi.org/10.1007/s11224-016-0850-6

8. Olah GA (1972) The general concept and structure of carbocations based on differentiation of trivalent ("Classical") carbenium ions from three-center bound penta- or tetracoordinated ("Nonclassical") Carbonium Ions. The Role of Carbocations in Electrophilic Reactions. J. Am. Chem. Soc. 94:808-820. https://doi.org/10.1021/ja00758a020

9. Gronowitz S (1997) Presentation speech at the Nobel Award Ceremony (in 1994). Nobel Lectures in Chemistry 1991-1995. World Scientific, Singapore, pp 139-140.

10. Olah, George A. (2015): A Life of Magic Chemistry: Autobiographical Reflections Including Post-Nobel Prize Years and the Methanol Economy. Second updated edition (with Mathew, Thomas). Hoboken, NJ: John Wiley \& Sons. https://doi.org/10.1002/9781118840108

11. Oláh György (2008) Félévszázadot felölelő, hagyományos határokon átlépő kutatások. A kémia újabb eredményei (szerk. Csákvári Béla) 100:17-59

12. Hargittai, Istvan, Hargittai, Balazs, Eds., Honoring George A. Olah. Structural Chemistry (special issue), 28:257-561. 


\section{To remember George A. Olah (1927-2017)}

George Olah (Oláh György) was born into an upper-middle-class family in Budapest. He attended the Catholic high school of the Piarist Order. He survived the Hungarian Holocaust thanks to the Lutheran Pastor Gabor Sztehlo, as part of Sztehlo's legendary action in saving numerous children in 1944?45. Olah completed his high school studies right upon the end of the war and enrolled at the Budapest Technical University. He graduated as a chemical engineer in 1949; the organic chemistry professor, Géza Zemplén was his mentor, who encouraged Olah to develop his independent research interest. Upon graduation, Olah became az assistant professor at the Technical University and participated in instruction. He also won a fellowship to pursue his doctoral studies. He defended his dissertation on his research in organic fluorine chemistry in 1954 and received his $\mathrm{PhD}$-equivalent degree. He continued his research, and in 1956, he submitted his DSc dissertation, a prerequisite for a professorial appointment. By the time the defense of this higher degree would have taken place Olah had already left Hungary. Olah published his best results in leading international journals and received recognition for his advances. At home, he was appointed deputy director of the newly organized Central Research Institute of Chemistry the Hungarian Academy of Sciences. When the anti-Soviet Hungarian revolution in 1956 was brutally supressed, Olah left the country and, via London, he moved to Canada. He found employment in an industrial laboratory where he continued his fundamental research in his own time while fulfilling his duties to his employer. In his research, using superacids, he succeeded prolonging the lifetime of the elusive non-classical 2-norbornilion and determined its structure. This achievement brought extraordinary visibility to Olah because it resolved a longstanding controversy between two leading organic chemists. The significance of Olah's discovery, however, was much broader, because by means of superacids he lent reactivity to the rather inert carbon-carbon and carbon-hydrogen sigma bonds of hydrocarbons, thereby he created a whole new chemistry. In the meantime, he moved back to academia, first at the Western Reserve University (Now, Case Western) and then at the University of Southern California (USC). At USC, a separate research institute, now the Loker Hydrocarbon Institute, was established for his project from funding by private sponsors.In 1994, Olah received the Nobel Prize in Chemistry for his contributions to carbocation chemistry. His research activities fortunately synergized synthetic chemistry, physical techniques of structure determination, and computational chemistry, involving the best representatives of the various specialities. In his activities, over the years, Olah always produced a monograph or edited a volume of the research topic he had completed. It was characteristic of his activities as a scientist that he always sought practical applications of his discoveries. In doing so the energy supply of humankind and the protection of the environment remained his pricipal concerns. He was a great scientist and a caring human being and his example will serve as a role model for generations to come. 